\title{
Corporate fraud as a threat to the company's economic security
}

\author{
Galina Krokhicheva, Iulia Mezentseva*, and Tian Yu \\ Don State Technical University, Gagarin Square 1, Rostov-on-Don, Russia
}

\begin{abstract}
The article is devoted to the study of the organizational and methodological foundations of ensuring economic security through the mechanism of preventing corporate fraud. The influence of "white-collar" crime at the micro level on the overall economic state of the state is considered. The theoretical aspects of corporate fraud are investigated and generalized. The analysis of existing methods and techniques to assess the risk of their occurrence in a particular enterprise is carried out. The emphasis is placed on the assessment of the external operating environment, considered as a source of potential threats to the company's security, as well as on the study of the risk of corporate fraud in relation to a particular business entity. The authors propose mechanisms to protect the economic interests of the organization from various threats from the staff, which are essential for maintaining the level of its economic security. The findings on the relationship between corporate fraud and micro-level economic security are not conclusive. This indicates the need for further scientific work on the problem, which will logically continue the problems raised in the article.
\end{abstract}

\section{Introduction}

Economic security is traditionally considered as the most important qualitative characteristic of the economic system, as the most important element of national security $[1,2]$.

The strategy of economic security of the Russian Federation, developed for the period up to 2030, requires improving approaches to strengthening security at all levels: international (mega-level), national (macro-level), regional/sectoral (meso-level), as well as at the level of the economic entity and the individual (micro-level) [3].

The economic, social, and political situation of the state over the past decade has been rather ambiguous. Some of the existing problems over the past year have worsened under the influence of the global COVID-19 pandemic, which has become a real stress test not only for the Russian, but also for the global economy. Such negative conditions cause risks to economic security at the macro, meso, and micro levels.

The central problem of achieving the set parameters of the state's economic security in these circumstances is the preservation of economic entities that form the core of the country's economic development.

\footnotetext{
*Corresponding author: mezentseva.y.r@mail.ru
} 
Each economic entity strives for growth, development, increase of income, increase of the level of its financial security. However, these goals are not always achieved by legal means. The difficult economic conditions of the last year provoked the growth of the phenomenon of corporate fraud in the country. They are one of the most significant threats to the economic security of the State. Countering this type of fraud is becoming increasingly important for managers and owners of the company.

The study of a significant number of scientific and practical works on the stated problems suggests that the issues of the relationship between corporate fraud and economic security remain insufficiently studied. From this point of view, the study of "white-collar" crime as a factor in ensuring economic security at the micro level is of strategic importance.

The purpose of this article is to study, generalize and systematize certain aspects of the impact of the threat of corporate fraud on the indicators of economic security of the enterprise, as well as to consider the mechanisms for protecting the economic interests of the organization in this situation.

Achieving this goal involves setting and solving the following tasks:

- to study and systematize the main aspects of corporate fraud, considered as a potential threat to the economic security of the company;

- to analyze the methods and techniques that allow you to assess the risk of corporate fraud, as well as to test some of them based on the materials of a particular enterprise.

Summarizing the above, the authors believe that the economic security of the company can not be achieved in conditions of ignoring the risk of corporate fraud, as well as the lack of effective mechanisms for their detection and prevention.

\section{Materials and methods}

Such an economic phenomenon as corporate fraud was first described by the American sociologist Edwin X. Sutherland in 1939. The scientist designated this phenomenon as white-collar crime ("white-collar crime" [4]). Corporate fraud has been studied by Howard R. Davia [5], Gerald L. Kovasich [6], J. T. Wells [7], D. O. Friedrichs [8,9], Furnham A. [10], Simpson S. S. [11] and many other authors.

Interest in the study of the phenomenon of corporate fraud in Russia arose only at the end of the 20th century, which is due to the peculiarities of the development of capitalist society in the state. Modern Russian authors actively explore this problem, including through the prism of total digitalization of society [12-17].

The Russian conditions for the functioning of enterprises impose their own characteristics on the concept of "corporate fraud". This is due to the fact that this concept is not legally fixed. Article 159 of the Criminal Code "Fraud" regulates the liability and specifics of all types of fraud, including corporate fraud, which is not singled out separately.

Qualifying crimes related to fraudulent transactions, there are five signs: intent (selfserving purpose); withdrawal and (or) treatment in favor of the guilty person or other persons of someone else's property; illegality; gratuitousness; causing damage to the owner.

The illegality of the act is explained by the commission of fraudulent actions in violation of existing norms of law, gratuitousness-the lack of compensation for the consumer value of the seized property. This act is inextricably linked with the sign of causing damage to the owner.

As it was mentioned, the Russian legislation does not disclose the exact definition of the concept of "corporate fraud". The Criminal Code of the Russian Federation does not formally contain such a category. However, he identifies various types of crimes that can, among other things, be committed by employees of the organization to the detriment of the interests of the organization itself. They should be classified as corporate fraud. This 
category includes the following crimes: theft, fraud, embezzlement or embezzlement, illegal receipt and disclosure of information constituting commercial, tax or banking secrets, abuse of authority, commercial bribery, corruption crimes (receiving and giving bribes).

It can be concluded that the category of corporate fraud in the Criminal Code of the Russian Federation qualifies more voluminously than the "fraud" itself in the broad sense [18].

At the same time, the absence of a single fixed concept of "corporate fraud" in the legislation of the Russian Federation allows enterprises to define this term in local documents based on the interests of the company.

There are different classifications of types of corporate fraud. Thus, according to the experts of the Association of Certified Fraud Examiners (ACFE), they can be divided into the following three groups:

- misappropriation of assets;

- corruption;

- reporting fraud [19].

Experts say that a typical organization loses about $5 \%$ of its gross income per year due to corporate fraud. This poses a significant threat to the economic security of economic entities.

Corporate scandals related to misleading investors and all interested users of financial statements about the real state of the company are increasingly widely publicized. We are talking about providing information in the reporting that does not correspond to reality. Corporate fraud affecting the interests of investors entails a huge risk of causing losses, undermines the business reputation of the company, thereby violating its economic security [20,21].

The results of the analysis of various tools for assessing the risk of corporate fraud allow us to draw conclusions:

- there is no established and effective methodological apparatus for studying this phenomenon, which emphasizes the complex debatable nature of the problem;

- regardless of the method of analysis, the result is some indicators, the assessment of which is subjective.

Corporate fraud causes significant damage to the organization, regardless of the way in which it is carried out. Therefore, an effective assessment of the risks of theft at enterprises is an important part of a set of measures aimed at countering fraud. Modern economic security services of enterprises should not only investigate the consequences of fraudulent actions, but also be able to anticipate and prevent them, trying to reduce economic losses to the lowest possible level.

\section{Research results and discussion}

The implementation of an effective system for preventing corporate fraud should be based on extensive research on this phenomenon in various contexts.

We are testing mechanisms for assessing the occurrence of threats to the company's economic security from employees.

As the object of the study, LLC "Don Construction Company"( was chosen, which is part of the largest holding company, which includes modern multi-profile companies of the construction direction.

Diagnostics and monitoring of personnel security of the economic entity under consideration can be carried out in quantitative and qualitative ways. 
The qualitative assessment focuses on the analysis of the external environment of the company's functioning, which is considered as a source of potential threats to the company's security.

In 2018, PricewaterhouseCoopers (PwC) conducted a worldwide survey of economic crimes. The results of this survey in relation to Russia will allow us to draw conclusions about the prevalence of the problem of corporate fraud in the environment of the functioning of Russian companies [22]. According to this survey, almost half of the Russian respondents, namely $49 \%$, reported that their companies had experienced corporate fraud over the past two years.

More detailed dynamics of the level of corporate fraud in Russia and the world according to the World Economic Crime Survey is shown in Figure 1.

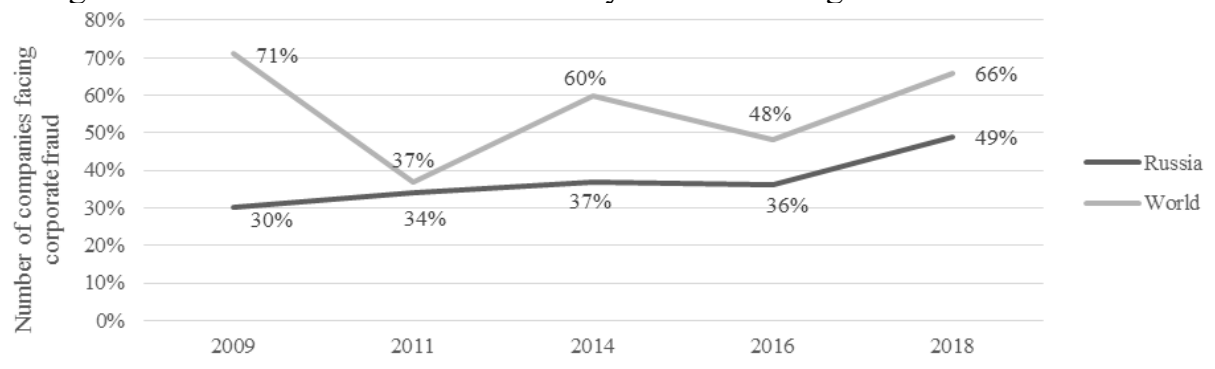

Fig. 1. The level of economic crime within the company in Russia and the world.

Based on the results of the study presented in Figure 1, we can conclude, firstly, that in Russia, compared to the global level, respondents are less likely to face economic crimes within the company. Secondly, in relation to Russia, in 2016 this indicator was significantly lower (36\%) than in 2018. This may indicate, on the one hand, an increase in the number of cases of corporate fraud, and, on the other, an increase in the level of attention to this problem and, as a result, an increase in awareness of fraud.

The distribution of the number of Russian companies that have faced various types of corporate fraud in comparison with the data of the 2016 and 2018 research is shown in Figure 2.

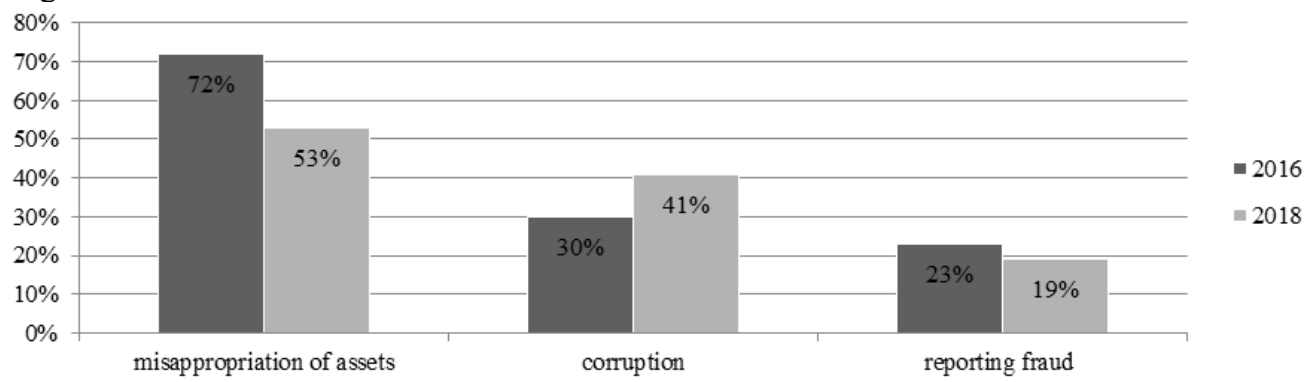

Fig. 2. Statistics of types of corporate fraud in Russian companies.

The analysis of the subject composition of corporate fraud will allow us to develop a more effective system for countering fraud.

Among Russian companies, $26 \%$ of cases of internal fraud are related to the management level. Financial services are in second place, accounting for $24 \%$ of cases. The procurement service was identified as a source of corporate fraud by $9 \%$ of respondents.

As part of the World Economic Crime Survey, conducted by PwC specialists in 2020, offenses in many areas were analyzed, including:

- manipulation of accounting data; 
- misappropriation of assets;

- bribery and corruption;

- fraudulent actions of employees [23].

Fraud risks surround organizations from all sides: the attacker may be one of the company's employees or act from outside, and in many cases, internal and external fraudsters act in collusion.

Thus, according to the research results, almost half of all organizations have faced fraud, which means that the probability that the analyzed company will face the fact of corporate fraud is quite high.

The probability of corporate fraud in the company is present at all stages of its activities. That is, absolutely any process in the organization should be considered as a potential source of risk of this type.

For an objective assessment of threats and available opportunities to prevent corporate fraud, we will carefully analyze the strengths and weaknesses of the company's activities, using the SWOT analysis method.

Table 1 shows the final matrix, which summarizes the results of the assessment of potential opportunities and threats, as well as takes into account the strengths and weaknesses of the enterprise.

Table 1. Assessment of the mutual influence of parameters within the framework of the SWOT analysis of the risk of corporate fraud in the company.

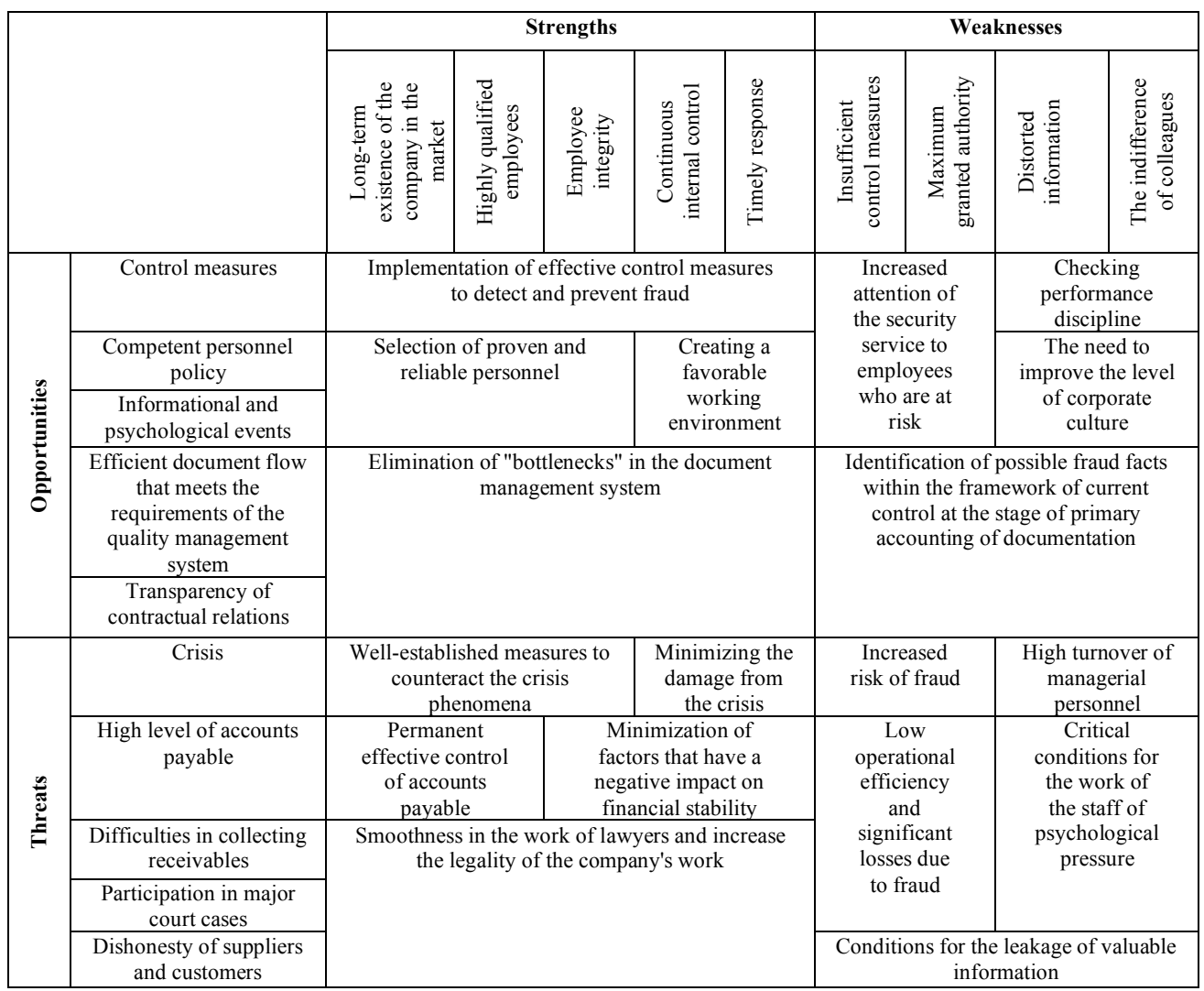

The conducted SWOT analysis of the risk of corporate fraud creates an extensive information field for the company's management, which ensures the adoption of management decisions. The competent use of the company's strengths in combination with 
the presented capabilities allows us to ensure the implementation of effective control measures to detect and prevent fraud and the selection of proven and reliable personnel, create favorable working conditions and eliminate "bottlenecks" in the document management system. At the same time, the strengths under the influence of external threats are to take advantage of well-established measures to counteract the crisis phenomena and minimize the damage from the economic crisis, to establish control over the level of accounts payable, to eliminate the factors of negative impact on financial stability.

However, the presence of weaknesses in the enterprise creates areas of activity to protect against corporate fraud. Opportunities allow you to increase the level of protection through: directing special attention of the security service to employees who are at risk, checking performance discipline, improving the level of corporate culture, identifying possible fraud within the framework of current control.

The weaknesses of the enterprise under the influence of threats create problems of an increased level of attention on the part of owners and management, the solution of which will contribute to the elimination of the increased risk of fraud.

We will pay special attention to the detection of fraud with accounting financial statements. We will use the method proposed in 1997 by M. Beneish [24]. The author deduced the relationship between the symptoms of possible fraud and a number of financial coefficients calculated from the reporting data.

For each indicator, a boundary value is defined, exceeding which increases the risk of falsification of reports at the enterprise. In 2011, the study of M. Beneisch was refined by Maria L. Roxas [25]. The improved model, which includes five indicators, is considered one of the most effective in detecting signs of fraud in financial statements.

To calculate the map of regulatory deviations for the analysis of signs of misstatement of the financial statements in LLC "Don Construction Company ", we use the data of the company's financial statements. The results of the calculations are summarized in Table 2.

Table 2. Application of the M. technique Beneisha for the analysis of" symptoms "of fraud in LLC" Don Construction Company».

\begin{tabular}{|c|c|c|}
\hline Indicator and designation & $\begin{array}{c}\text { Boundar } \\
\text { y value }\end{array}$ & $\begin{array}{c}\text { According to } \\
\text { the calculations }\end{array}$ \\
\hline Daily sales index in accounts receivable (DSRI) & 1,031 & 0,8050 \\
\hline Gross Margin Return on Sales Index (GMI) & 1,014 & 0,8086 \\
\hline Asset Quality Index (AQI) & 1,039 & 66,9138 \\
\hline Sales Growth Index (SGI) & 1,134 & 1,5955 \\
\hline Depreciation Index (DEPI) & 1,000 & 0,6007 \\
\hline
\end{tabular}

The composite index, the so-called M-score, is calculated using the formula 1 [25]:

$$
M-\text { score }=-6,065+0,823 D S R I+0,906 G M I+0,593 A Q I++0,717 S G I+0,107 D E P I
$$

It assesses the risk of falsification of financial statements in the company. If the value of this composite index exceeds minus 2.76 , then the company's employees are very likely to commit fraudulent actions, somehow falsifying the financial statements.

Calculation of this composite index for the company: 
M-score $=-6,065+0,823 * 0,8050+0,906 * 0,8086+0,593 * 66,9138++0,717 * 1,5955$ $+0,107 * 0,6007=-6,065+0,6625+0,7326+39,6799+1,1439+0,0642=36,2181$.

The resulting composite index according to the method of M. Roxas (36.2181) does not exceed the standard (-2.76). Thus, based on the results of the calculations, it can be concluded that the financial statements of LLC "Don Construction Company" were not subjected to distortions by the company's employees. However, it should be noted that exceeding the marginal value of the revenue growth index (SGI) increases the risk of falsification of financial statements, in which fictitious contracts are concluded with counterparties.

The effectiveness of the security service in detecting corporate fraud is achieved with a well-defined locally fixed algorithm of actions.

The set of measures to identify and eliminate the facts of abuse is conditionally divided into the monitoring stage and the verification stage.

At the monitoring stage, the responsible person needs to assess the risk of corporate fraud and distribute the degree of activity of their actions among the selected business processes. At this stage, the internal processes of the company are divided into:

- processes that require constant in-depth control and monitoring of employees;

- processes that require monitoring for the appearance of fraud indicators.

Special attention should be paid to the following indicators of corporate fraud:

- lifestyle is not based on income;

- the employee's unwillingness to go on vacation and allow access to their documents;

- countering the conduct of audits;

- providing copies, not originals of documents;

- unexpected shortages or surpluses;

- corrections in the documents;

- staff turnover in positions associated with potential fraudulent risks;

- the presence of leads, denunciations and complaints.

In the presence of these signs or their combination, you can talk about the suspicion of committing an offense by an employee of the organization. Every case needs to be investigated. This will allow you to objectively and fully establish all the facts, as well as collect evidence for disciplinary action or contacting the police.

The second stage of the algorithm is directly related to conducting a check to detect corporate fraud. The activities of this stage are divided into system data analysis and internal investigation. Using system data analysis, a large volume of data is analyzed, the purpose of which is to detect suspicious transactions. If you find evidence of corporate fraud, you need to start an internal investigation, which will help determine what the employee committed: a misdemeanor, an offense, or a crime.

After conducting an internal investigation, identifying the culprit and compensating for damages, it is necessary to analyze the system for combating corporate fraud in the enterprise. It is necessary to establish the "weak point" that allowed the fraudster to bring damage to the company. After this analysis, the fraud prevention program is adjusted in connection with the identified shortcomings of the system.

Thus, based on the compiled programs, DSK LLC will fully develop a comprehensive system of personnel security. When ensuring the safety of the company's main resource-the personnel-its economic security is achieved, among other things.

\section{Conclusion}

Fraud risks surround organizations from all sides. Each organization can be subject to fraud from its own employees, regardless of their position and length of service in the organization, and in many cases, internal and external fraudsters act in collusion. We can 
safely say that for the company, employees are not only a source of added value, but also a risk generator. Human capital becomes the most important factor in ensuring the economic security of the enterprise. Therefore, this study considers the need to analyze the risk of corporate fraud in the company as an important condition for ensuring economic security at the micro level. Algorithms for the implementation of measures to identify and establish the facts of corporate fraud are proposed. This algorithm will help to detect fraud in a timely manner, identify the perpetrators, compensate for damage and make adjustments to the fraud prevention system, which in turn will contribute to achieving a given level of economic security of the company.

\section{References}

1. Godina, Y.Y. Kosenkova, L.S. Maksimenko, Y.R. Mezentseva, T.A. Shcherbakova Strategic Directions of Innovational Development of Socio-Economic Systems. In: Popkova E., Ostrovskaya V. (eds) Perspectives on the Use of New Information and Communication Technology (ICT) in the Modern Economy. ISC 2017. Advances in Intelligent Systems and Computing, vol 726. Springer, Cham DOI: https://doi.org/10.1007/978-3-319-90835-9 14 (2019)

2. On the national goals and strategic objectives of the development of the Russian Federation for the period until 2024: Decree of the President of the Russian Federation of 05.05.2018 No. 204 http://www.consultant.ru/document/cons_doc_LAW_297432 (2018)

3. On the Economic Security Strategy of the Russian Federation for the period up to 2030: Decree of the President of the Russian Federation dated 05.13.2017 No. 208. http://www.consultant.ru/document/cons_doc_LAW_216629/1d8dcf5824d $5241136 \mathrm{fa} 09 \mathrm{~b} 9 \mathrm{e} 9 \mathrm{c} 672 \mathrm{ac} 5 \mathrm{~d} 325365$ (2017)

4. Sutherland, Edwin H. White Collar Crime / Foreword by Donald R. Cressey. Westport, Conn.: Greenwood Press. - 272 p. (1983)

5. Howard R. Davia. Fraud: methods of detection / Trans. from English. St. Petersburg: DNK (2005)

6. Gerald L. Kovasich Countering Fraud. How to develop and implement a program of events / Trans. from English - M.: Maroseyka (2010)

7. Wells J. T. Guide to prevention and detection of corporate fraud (2011)

8. Friedrichs D. O. Trusted Criminals: White Collar Crime in Contemporary Society / 4th Edition. Belmont, CA USA (2010)

9. Friedrichs D.O. Occupational crime, occupational deviance, and workplace crime: Sorting out the difference /D.O. Friedrichs // Criminal Justice. Vol. 2 (3). P. 243-256 (2002)

10. Furnham A. The dark side of behavior at work. Understanding and avoiding employees leaving, thieving and deceiving / A. Furnham, J. Taylor. Palgrave, 300 p. (2004)

11. Simpson S.S. The Criminology of White-Collar Crime / S.S. Simpson, D. Weisburd. - Springer, 228 p. (2009)

12. Kirilenko V. P., Dronov R. V., Shunaev A.M. The mechanism of neutralization of the corruption threat in the commercial sector of the economy. №6 (102). DOI 10.22394/1726-1139-2017-6-47-53 (2017)

13. Mezentseva Yu. R., Verdesh K. A. The role of internal audit in the suppression and prevention of corporate fraud. Collection: modern problems of an economic safety, accounting and the right in the Russian Federation. V.3 DOI: 10.26526/conferencearticle_5c5060ceeb8df2.85068792(2018) 
14. G.E. Krokhicheva, J.R. Mezentseva, E.L. Arkhipov, E.M. Evstafieva. Digital accounting platform / (2020) [et al.] // E3S Web of Conferences. Vol. 224. - 8 p. Article 03008. - (Topical Problems of Agriculture, Civil and Environmental Engineering (TPACEE 2020), Moscow, Russia, November 25-27, 2020). - DOI https://doi.org/10.1051/e3sconf/202022403008 16 (2020)

15. Peshkova G. Yu., Samarina A. Yu. Digital economy and recruitment potential: Strategical interconnection and prospects. The Education and Science Journal. 10 (20): 50-75. DOI: 10.17853/1994-5639-2018-10-50-75 (2018)

16. Podolniy N.A., Podolnaya N.N. Corporate corruption: the substantiation of the problem. Vserossiiskii kriminologicheskii zhurnal = Russian Journal of Criminology, vol. 10, no. 3, pp. 521-530. DOI: 10.17150/2500-4255.2016.10(3).521-530. (In Russian) (2016)

17. Skipin D.L., Bystrova A.N., Kutyreva E.V., Trufanova K.N. Corporate fraud: the essence, risks and impact on economic security of business. Rossiyskoe predprinimatelstvo. 18. (22). - 3605-3614. doi: 10.18334/rp.18.22.38446 (2017)

18. Vinokurov M.A., Kuznetsova N.V. Ensuring personnel security of the company: criminological aspect. Criminology Journal of Baikal National University of Economics and Law, no. 4, pp. 54-64. (In Russian). DOI: 10.17150/19967756.2014.8(4).54-64 (2014)

19. Report to the Nations on Occupational Fraud and Abuse. 2016. Global Fraud Study. Association of Certified Fraud Examiners, Inc. (2016)

20. Bryukhanov M. Yu. The economic nature of falsification of financial statements / / Finance: theory and №ctice. №1. URL: https://cyberleninka.ru/article/n/ekonomicheskaya-priroda-falsifikatsii-finansovoyotchetnosti (2008)

21. Safonova I. V., Silchenko A. D. Falsification of financial statements: Concept and tools of identification. Uchet. Analiz. Audit $=$ Accounting. Analysis. Auditing. 5(6):37-49. (In Russ.). DOI: 10.26794/2408-9303-2018-5-6-37-49 (2018)

22. Combating fraud: measures taken by companies Russian Economic Crime and Fraud Survey 2018 URL: https://www.pwc.ru/en/forensic-services/assets/PwC-RECS-2018eng.pdf (2018).

23. Fighting fraud: A never-ending battle. PwC's Global Economic Crime and Fraud Survey. URL: https:/www.pwc.com/gx/en/forensics/gecs-2020/pdf/global-economiccrime-and-fraud-survey-2020.pdf (2020)

24. Beneish M.D. Detecting GAAP Violation: Implications for Assessing Earnings Management among Firms with Extreme Financial Performance. Journal of Accounting and Public Policy, vol. 16, iss. 3, pp. 271-309. https://doi.org/10.1016/S0278-4254(97)00023-9 (1997)

25. Roxas M. 2011. Financial statement fraud detection using ratio and digital analysis. Journal of Leadership, Accountability and Ethics 8 (4): 56-66. 